\title{
List of Writings of Peter Boomgaard
}

\author{
Forthcoming
}

Books

Histories of the Forests of Java, 1500-1950 [working title].

\section{Edited Volumes}

With Raquel Reyes, The Senses in Southeast Asian Pasts: Forms of Perception across two Millennia. London/New York: Routledge.

\section{Articles}

With Pieter M. Kroonenberg, "Rice, Sugar, and Livestock in Java, 1820-1940: Geertz's Agricultural Involution 50 years on." In Rice: Global Networks and New Histories, edited by Francesca Bray et al. Cambridge: Cambridge University Press.

"Environmental Histories of Southeast Asia." In Handbook of the Environment in Southeast Asia, edited by Philip Hirsch. London/New York: Routledge.

"Smells and Sounds of the City: Batavia, Java, in the 17th and 18th Centuries." In The Senses in Southeast Asian Pasts: Forms of Perception across two Millennia, edited by Raquel Reyes and Peter Boomgaard. London/New York: Routledge.

\section{Published}

\section{Books}

Southeast Asia: An Environmental History. Santa Barbara: ABC-CLIO, 2007, 377 pp.

Anak Jajahan Belanda: Sejarah Sosial dan Ekonomi Jawa 1795-1880. Jakarta: KITLV Jakarta/Djambatan, 2004, 413 pp. [Translation of Children of the Colonial State, Amsterdam: vu University Press.]

Frontiers of Fear: Tigers and People in the Malay World, 1600-1950. New Haven/London: Yale University Press, 2001, 306 pp.

With Janneke van Dijk. Het Indië Boek. Zwolle: Waanders, 2001, 512 pp.

With the assistance of R. de Bakker. Forests and Forestry 1823-1941. Amsterdam: KIT, 1996, 184 pp. [Changing Economy in Indonesia 16.]

With A.J. Gooszen. Population Trends 1795-1942. Amsterdam: KIT, 1991, 256 pp. [Changing Economy in Indonesia 11.]

With J.L. van Zanden. Food Crops and Arable Lands, Java 1815-1942. Amsterdam: KIT, 1990, 144 pp. [Changing Economy in Indonesia 10.] 
Between Sovereign Domain and Servile Tenure: The Development of Rights to Land in Java, 1780-1870. Amsterdam: Free University Press, 1989, 55 pp. [Comparative Asian Studies 4.]

Children of the Colonial State: Population Growth and Economic Development in Java: 1795-1880. Amsterdam: vU University Press, 1989, 247 pp. [CASA Monographs 1.]

\section{Edited Volumes}

Empire and Science in the Making - Dutch Colonial Scholarship in Comparative Global Perspective, 1760-1830. New York/Houndmills, Basingstoke: Palgrave Macmillan, 2013, $320 \mathrm{pp}$.

Special Issue: "Long-Term Changes in Land-Tenure Arrangements in Pre-Modern and Early-Modern Southeast Asia." Journal of the Economic and Social History of the Orient 54 (4), 2011, pp. 447-519.

With Marjolein 't Hart. Globalization, Environmental Change and Social History. Cambridge: Cambridge University Press, 2010, 233 pp. [Also published as a Special Issue of International Review of Social History (volume 55, issue S18, 2010).]

With David Henley. Credit and Debt in Southeast Asia, 860-1930: From Peonage to Pawnshop, from Kongsi to Cooperative. Singapore: ISEAS, 2009, 195 pp.

With Dick Kooiman and Henk Schulte Nordholt. Linking Destinies: Trade, Towns and Kin in Asian History. Leiden: KITLV, 2008, 277 pp.

A World of Water: Rain, Rivers and Seas in Southeast Asian Histories. Leiden: KITLV Press, 2007, 368 pp.

With Greg Bankoff. A History of Natural Resources in Asia: The Wealth of Nature. New York/Houndmills, Basingstoke: Palgrave Macmillan, 2007, 288 pp.

With David Henley and Manon Osseweijer. Muddied Waters: Historical and Contemporary Perspectives on Management of Forests and Fisheries in Island Southeast Asia. Leiden: KITLv Press, 2005, 418 pp.

With David Henley. Smallholders and Stockbreeders: Histories of Foodcrop and Livestock Farming in Southeast Asia. Leiden: KITLV Press, 2004, 344 pp.

With Ian Brown. Weathering the Storm: The Economies of Southeast Asia in the $1930 \mathrm{~s}$ Depression. Singapore: ISEAS, Leiden: KITLV Press, 2000, 332 pp.

With Freek Colombijn and David Henley. Paper Landscapes: Explorations in the Environmental History of Indonesia. Leiden: KITLV Press, 1997, 424 pp.

With Harry A. Poeze and Gerard Termorshuizen. God in Indië: Bekeringsverhalen uit de Negentiende Eeuw. Leiden: KITLV Uitgeverij, 1997, 156 pp.

With Rosalia Sciortino and Inez Smyth. Health Care in Java: Past and Present. Leiden: KITLV Press, 1996, 197 pp. [KITLv Proceedings 3.]

With Harry Poeze and Gerard Termorshuizen. Aangeraakt door Insulinde. Leiden: KITLV Uitgeverij, 1992, 143 pp. 
With Paul Alexander and Ben White. In the Shadow of Agriculture: Non-farm Activities in the Javanese Economy, Past and Present. Amsterdam: KIT, 1991, 154 pp.

The Colonial Past: Dutch Sources on Indonesian History. Amsterdam: KIT, 1991, 63 pp. [Bulletin 323, Royal Tropical Institute.]

With L. Noordegraaf, H. De Vries, and W.M. Zappey. Exercities in ons Verleden: Twaalf Opstellen over de Economische en Sociale Geschiedenis van Nederland en Koloniën, 180o-1950: Aangeboden aan Prof. W.J. Wieringa. Assen: Van Gorcum, 1981, $254 \mathrm{pp}$.

\section{Articles in Refereed Journals}

"Long-Term Changes in Land-Tenure Arrangements in Pre-Modern and Early-Modern Southeast Asia: An Introduction." Journal of the Economic and Social History of the Orient 54 (4) (2011): 447-454.

"Land Rights and the Environment in the Indonesian Archipelago, 800-1950." Journal of Economic and Social History of the Orient 54 (4) (2011): 478-496.

With Marjolein 't Hart. Special Issue 18: "Globalization, Environmental Change and Social History: An Introduction.” International Review of Social History 55 (2010): 1-26. [Edited by Peter Boomgaard and Marjolein 't Hart.]

"Droefenis en Duurzaamheid: Beheer en Exploitatie van de Bossen op Java onder Daendels (1808-1810)." Jaarboek voor Ecologische Geschiedenis 2009 (2010): $59-84$.

"Labour, Land, and Capital Markets in Early Modern Southeast Asia from the Fifteenth to the Nineteenth Century." Continuity and Change 24 (1) (2009): 55-78.

"Technologies of a Trading Empire: Dutch Introduction of Water- and Windmills in Early-modern Asia, 1650s-180o." History and Technology 24 (1) (2008): 41-59.

"Syphilis, Gonorrhoea, Leprosy and Yaws in the Indonesian Archipelago, 1500-1950." Manusya, Journal of Humanities 14 (2007): 20-41.

"Zeven Eeuwen Confrontaties tussen Mens en Tijger." Leidschrift 21 (1) (2006): 73-88.

“Tijgerstekerijen en Tijger-Buffelgevechten op Java, 1620-1906." Indische Letteren 21 (1) (2006): $45^{-56 .}$.

"The Making and Unmaking of Tropical Science: Dutch Research on Indonesia, 1600200o." Bijdragen tot de Taal-, Land- en Volkenkunde 162 (2/3) (2006): 191-217.

"Bridewealth and Birth Control: Low Fertility in the Indonesian Archipelago, 1500190o." Population and Development Review 29 (2) (2003): 197-214.

"In the Shadow of Rice: Roots and Tubers in Indonesian History, 1500-1950." Agricultural History 77 (4) (2003): 582-610.

"Human Capital, Slavery and Low Rates of Economic and Population Growth in Indonesia, 1600-1910." Slavery \& Abolition: A Journal of Slave and Post-Slave Studies 24 (2) (2003): 83-96. 
"Smallpox, Vaccination, and the 'Pax Neerlandica': Indonesia, 1550-1930." Bijdragen tot de Taal-, Land- en Volkenkunde 159 (4) (2003): 590-617.

"From Subsistence Crises to Business Cycle Depressions, Indonesia 1800-1940." Itinerario 26 (3-4) (2002): 35-49.

"Oriental Nature, its Friends and its Enemies: Conservation of Nature in Late-Colonial Indonesia, 1889-1949." Environment and History 5 (3) (1999): 257-292.

"Het Javaanse Boerenbedrijf, 1900-1940." NEHA-Jaarboek voor Economische, Bedrijfs- en Techniekgeschiedenis 62 (1999): 173-185.

"Environmental Impact of the European Presence in Southeast Asia, 17th-19th centuries." Illes i Imperis (1) (1998): 21-35.

"The Miracle of the Second Flowering: Recent Developments in Southeast Asian Studies in Europe." Southeast Asian Studies 35 (1) (1997): 164-169.

“Ten geleide." Spiegel Historiael 32 (10/11) (1997): 414-417. [Special issue: "People and Nature in Indonesia: Environmental History 1500-present."]

"Gevolgen van de Introductie van Nieuwe Landbouwgewassen (1600-1900)." Spiegel Historiael 32 (10/11) (1997): 418-423. [Special issue: "People and Nature in Indonesia: Environmental History 1500-present."]

"Death to the Tiger! The Development of Tiger and Leopard Rituals in Java, 1605-1906." South East Asia Research 2 (2) (1994): 141-175.

"Historical Studies in 150 volumes of Bijdragen." Bijdragen tot de Taal-, Land-en Volkenkunde 150 (4) (1994): 685-702.

"The Development of Colonial Health Care in Java: An Exploratory Introduction." Bijdragen tot de Taal-, Land- en Volkenkunde 149 (1) (1993): 77-93.

"Forest Management and Exploitation in Colonial Java, 1677-1897." Forest and Conservation History 36 (1) (1992): 4-14.

"The Tropical Rain Forests of Suriname: Exploitation and Management 1600-1975." New West Indian Guide/Nieuwe West-Indische Gids 66 (3-4) (1992): 207-235.

"The Javanese Village as a Cheshire Cat: The Java Debate against a European and Latin American Background." The Journal of Peasant Studies 18 (2) (1991): 288-304.

"Why Work for Wages? Free Labour in Java, 1600-190o." Economic and Social History in the Netherlands 2 (1990): 37-56.

"'Rough Music' outside Europe: the case of Nineteenth-century Java." Economic and Social History in the Netherlands 1 (1989): 141-148.

With GertJ. Oostindie. "Changing SugarTechnology and the Labour Nexus:The Caribbean, 1750-1900." Nieuwe West-Indische Gids/New West Indian Guide 63 (1/2) (1989): 5-15.

"De Welvaartspolitiek in Nederlands-Indië (1900-1942)." Spiegel Historiael 22 (9) (1987): $382-387$.

"Multiplying Masses: Nineteenth Century Population Growth in India and Indonesia." Itinerario 11 (1) (1987): 135-148. 
"Buitenzorg in 1805: The Role of Money and Credit in a Colonial Frontier Society." Modern Asian Studies 20 (1) (1986): 33-58.

With W.L. Korthals Altes. "Indonesië's Verleden in Cijfers: Het Project 'Changing Economy in Indonesia"' Orion 2 (5) (1986): 35-37.

"The Welfare Services in Indonesia, 1900-1942." Itinerario 10 (1) (1986): 57-81.

"Arbeidersgeschiedenis in Nederland: Een Proeve tot een Sociale Psychologie." Tijdschrift voor Sociale Geschiedenis 10 (4) (1984):368-379. [This article was awarded a prize in 1985 by the SociaalWetenschappelijke Raad of the Koninklijke Nederlandse Akademie van Wetenschappen.]

"Population Growth and Welfare in Java (1800-1942)." Kabar Seberang 13/14 (1984): 82-102.

"Surinam Plantations in Dutch Archives." Itinerario 6 (1) (1982): 121-126.

"Female Labour and Population Growth in Nineteenth Century Java." Review of Indonesian and Malayan Affairs 15 (2) (1981): 1-34.

"Bevolkingsgroei en Welvaart op Java, 1800-1942." Intermediair 15 (32) (1979): 25-35.

"Revolutie als Theoretische Categorie." Lampas 11 (2) (1978): 70-95.

"De Havenstaking van 1946 in Amsterdam en Rotterdam: Confrontatie met Conflict en Stakingstheorieën." Economisch- en Sociaal-Historisch Jaarboek 40 (1977): 242-312. “¿Una revolución inevitable? México 1876-1911.” Colmena Universitaria 3 (1975): 12-38. [Univ. de Guanajuato, Mexico.]

\section{Articles in Edited Volumes}

"The Demographic History of Southeast Asia in the Twentieth Century." In Histories of Health in Southeast Asia: Perspectives on the Long Twentieth Century, edited by Tim Harper and Sunil S. Amrith, 87-98. Bloomington: Indiana University Press, 2014.

"From the Mundane to the Sublime: Science, Empire, and the Enlightenment (1760s-1820s)." In Empire and Science in the Making - Dutch Colonial Scholarship in Comparative Global Perspective, 1760-1830, edited by Peter Boomgaard, 1-37. New York/Houndmills, Basingstoke: Palgrave Macmillan, 2013.

"For the Common Good: Dutch Institutions and Western Scholarship on Indonesia around 180o." In Empire and Science in the Making - Dutch Colonial Scholarship in Comparative Global Perspective, 1760-1830, edited by Peter Boomgaard, 135-164. New York/Houndmills, Basingstoke: Palgrave Macmillan, 2013.

"Population Growth and Environmental Change: A Two-Track Model." In The Routledge Handbook of Southeast Asian History, edited by Norman Owen, 133-143. London/ New York: Routledge, 2013.

"Southeast Asia in Global Environmental History." In A Companion to Global Environmental History, edited by J.R. McNeill and Erin Stewart Mauldin, 81-95. Malden: Wiley-Blackwell, 2012. 
"Male-Male Sex, Bestiality and Incest in the Early-Modern Indonesian Archipelago: Perceptions and Penalties." In Sexual Diversity in Asia, c. 6oo-1950, edited by Raquel A.G. Reyes and William G. Clarence-Smith, 141-16o. London/New York: Routledge, 2012.

"Shame, Savings, and Colonial Expansion: Patterns of Migration and Family Structure in Sumatra and Java, 1800-1950." In Southeast Asian Historiography: Unravelling the Myths: Essays in Honour of Barend Jan Terwiel, edited by Volker Grabowsky, 236-247. Bangkok: River Books, 2011.

"Tigers and People in the Malay World: Four Centuries of Confrontation and Co-existence in Comparative Asian Perspective." In Tigers of the World: The Science, Politics and Conservation of Panthera tigris, edited by Ronald Tilson and Philip J. Nyhus, 349-356. London: Academic Press, 2010.

"Following the Debt': Credit and Debt in Southeast Asian Legal Theory and Practice, 1400-1800." In Credit and Debt in Southeast Asia, 860-1930: From Peonage to Pawnshop, from Kongsi to Cooperative, edited by David Henley and Peter Boomgaard, 61-79. Singapore: ISEAS, 2009.

"Writing Medical Histories of Southeast Asia: Comparative Approaches to Disease, Health and Healing." In Proceedings First International Conference on the History of Medicine in the Philippines, January $9 \& 10,2007$, Manila, Philippines, edited by Angel Aparicio, 1-16. Manila: Miguel de Benavides Library, University of Santo Tomas, 2008. With Henk Schulte Nordholt. "Connecting People, Places, and Commodities." In Linking Destinies: Trade, Towns and Kin in Asian History, edited by Peter Boomgaard, Dick Kooiman and Henk Schulte Nordholt, 1-12. Leiden: KITLV, 2008.

"Early Globalization: Cowries as Currency, 600 BCE-19oo." In Linking Destinies: Trade, Towns and Kin in Asian History, edited by Peter Boomgaard, Dick Kooiman and Henk Schulte Nordholt, 13-28. Leiden: KITLV, 2008.

"Horse Breeding, Long-Distance Horse Trading and Royal Courts in Indonesian History, 1500-1900." In Breeds of Empire: The "Invention" of the Horse in Southeast Asia and Southern Africa, 1500-1950, edited by Greg Bankoff and Sandra Swart, 33-49. Copenhagen: NIAS, 2007.

"In a State of Flux: Water as a Deadly and a Life-Giving Force in Southeast Asia." In $A$ World of Water: Rain, Rivers and Seas in Southeast Asian Histories, edited by Peter Boomgaard, 1-23. Leiden: KITLV Press, 2007.

With Greg Bankoff. "Introduction: Natural Resources and the Shape of Asian History, 1500-2000." In A History of Natural Resources in Asia: The Wealth of Nature, edited by Greg Bankoff and Peter Boomgaard, 1-17. New York/Houndmills, Basingstoke: Palgrave Macmillan, 2007.

"From Riches to Rags? Rice Production and Trade in Asia, Particularly Indonesia, 15001950." In A History of Natural Resources in Asia: The Wealth of Nature, edited by Greg 
Bankoff and Peter Boomgaard, 185-203. New York/Houndmills, Basingstoke: Palgrave Macmillan, 2007.

"Cockfights and Quailfights in Indonesia, 800-1950: Male versus Female Aggression." In Les Messagers divins: Aspects esthétiques et symboliques des Oiseaux en Asia du Sud-Est/Divine Messengers; Bird Symbolism and Aesthetics in Southeast Asia, edited by Pierre Le Roux and Bernard Sellato, 119-16o. [n.p.]: Éditions Connaissances et Savoir/SevenOrients/IRASEC, 2006.

"Products and People of the Sea in and around the Indonesian Archipelago, 900-1900."

In Muddied Waters: Historical and Contemporary Perspectives on Management of Forests and Fisheries in Island Southeast Asia, edited by Peter Boomgaard, David Henley, and Manon Osseweijer, 97-120. Leiden: KITLV Press, 2005.

"The Long Goodbye? Trends in Forest Exploitation in the Indonesian Archipelago, 1600-200o." In: Muddied waters: Historical and Contemporary Perspectives on Management of Forests and Fisheries in Island Southeast Asia, edited by Peter Boomgaard, David Henley, and Manon Osseweijer, 211-234. Leiden: KITLV Press, 2005 .

“Primitive' Tiger Hunters in Indonesia and Malaysia, 1800-1950." In Wildlife in Asia: Cultural Perspectives, edited by John Knight, 185-206. London/New York: RoutledgeCurzon, 2004.

"Steden met een Verleden." In Andere Verhalen over Azië en Onderzoek: Aangeboden aan Ot van den Muijzenberg bij zijn Afscheid als Hoogleraar Sociologie en Moderne Geschiedenis van Niet-westerse Samenlevingen, in het Bijzondervan Zuid-en ZuidoostAzië, aan de Universiteit van Amsterdam, edited by Rosanne Rutten and Loes Schenk-Sandbergen, 114-118. Amsterdam: Het Spinhuis, 2004.

"Demographic Transition in Southeast Asia." In Southeast Asia: A Historical Encyclopedia, from Angkor Wat to East Timor, edited by Ooi Keat Gin, 414-418. Vol. 1. Santa Barbara: ABC-CLIO, 2004.

With David Henley. "Agriculture and Livestock Histories of Southeast Asia: Approaches and Perspectives." In Smallholders and Stockbreeders: Histories of Foodcrop and Livestock Farming in Southeast Asia, edited by Peter Boomgaard and David Henley, 1-16. Leiden: KITLV Press, 2004.

"Horses, Horse-Trading, and Royal Courts in Indonesian History, 1500-1900." In Smallholders and Stockbreeders: Histories of Foodcrop and Livestock Farming in Southeast Asia, edited by Peter Boomgaard and David Henley, 211-232. Leiden: KITLV Press, 2004.

"The Age of the Buffalo and the Dawn of the Cattle Era in Indonesia, 1500-1850." In Smallholders and Stockbreeders: Histories of Foodcrop and Livestock Farming in Southeast Asia, edited by Peter Boomgaard and David Henley, 257-282. Leiden: KITLV Press, 2004. 
"Human Capital, Slavery and Low Rates of Economic and Population Growth in Indonesia, 1600-1910." In The Structure of Slavery in Indian Ocean Africa and Asia, edited by Gwyn Campbell, 83-96. London/Portland: Frank Cass, 2004.

"The High Sanctuary: Local Perceptions of Mountains in Indonesia, 1750-200o." In Framing Indonesian Realities: Essays in Symbolic Anthropology in Honour of Reimar Schefold, edited by Peter Nas, Gerard Persoon and Rivke Jaffe, 295-314. Leiden: KITLV Press, 2003.

With Ben White and Milan Titus. "The Experience of Crisis in Indonesia: Comparative, local and historical dimensions." In Indonesia in Search of Transition, edited by Henk Schulte Nordholt and Irwan Abdullah, 149-176. Yogyakarta: Pustaka Pelajar, 2002.

"Jagung dan Tembakau di Dataran Tinggi Indonesia, 1600-1940." In Proses Transformasi Daerah Pedalaman di Indonesia, edited by Tania Murray Li, 75-124. Jakarta: Obor, 2002.

"Crisis Mortality in Seventeenth-Century Indonesia." In Asian Population History, edited by Ts'ui-jung Liu et al., 191-220. Oxford: Oxford University Press, 2001.

"A Bird's-Eye View of Economic and Social Development in the District of Comal, $175^{0}-$ 1940." In Beneath the Smoke of the Sugar-Mill:Javanese Coastal Communities during the Twentieth Century, edited by Hiroyoshi Kano, Frans Hüsken and Djoko Suryo, 9-37. Yogyakarta: Akatiga \& Gadjah Mada University Press, 2001.

"Changing Economic Policy." In South East Asia: Colonial History. Volume III: High Imperialism (189os-1930s), edited by Paul H. Kratoska, 77-94. London/New York: Routledge, 2001.

"Peper, Goud en Menseneterij." In Oosterse omzwervingen: Klassieke teksten over Indonesië uit Oost en West, edited by Harry A. Poeze, 187-190. Leiden: KITLV Uitgeverij, 2000.

With Ian Brown. "The Economies of Southeast Asia in the 1930s Depression: An introduction." In Weathering the Storm: The Economies of Southeast Asia in the $1930 \mathrm{~s}$ Depression, edited by Peter Boomgaard and Ian Brown, 1-19. Singapore/Leiden: ISEAS/KITLV Press, 2000.

"Surviving the Slump: Development in Real income During the Depression of the 1930s in Indonesia, particularly Java." In Weathering the Storm: The Economies of Southeast Asia in the 1930 Depression, edited by Peter Boomgaard and Ian Brown, 23-52. Singapore/Leiden: ISEAS/KITLV Press, 2000.

"Kekayaan-kekayaan Haram: Perkembangan Ekonomi dan Perubahan Sikap terhadap Uang dan Kekayaan Seperti Tercermin dalam Kepercayaan Jawa Populer." In Sejarah Ekonomi Modern Indonesia:Bergabai Tantangan Baru, edited by J. Thomas Lindblad, 281-307. Jakarta: LP3ES, 2000.

"Maize and Tobacco in Upland Indonesia, 1600-1940." In Transforming the Indonesian Uplands: Marginality, Power and Production, edited by Tania Murray Li, 45-78. Amsterdam: Harwood Academic Publishers, 1999. 
"Het Regenwoud en de Ontwikkeling van de Landbouw." In Geschiedenis van Indonesië: Land, Volk en Cultuur. Deel 2, Vroeg-moderne Geschiedenis, edited by A. Reid, 166167. Abcoude: Uniepers, 1998.

"Voedsel, Feest en Hongersnood." In Geschiedenis van Indonesië:Land, Volk en Cultuur. Deel 2, Vroeg-moderne Geschiedenis, edited by A. Reid, 168-169. Abcoude: Uniepers, 1998.

"Nederlands Bestuur en de Bevolkingsexplosie." In Geschiedenis van Indonesië: Land,

Volk en Cultuur. Deel 2, Vroeg-moderne Geschiedenis, edited by A. Reid, 274-275. Abcoude: Uniepers, 1998.

"The voc Trade in Forest Products in the 17th Century." In Nature and the Orient: The Environmental History of South and Southeast Asia, edited by R.H. Grove, V. Damodaran and S. Sangwan, 375-395. Oxford University Press, 1998.

"Peningkatan yang Sia-sia? Dampak Langkah-langkah Kesejahteraan pada masa Kolonial lanjut di Indonesia." In Pembangunan dan Kesejahteraan Sosial: Indonesia di bawah Orde Baru, edited by F. Hüsken, M. Rutten and J.-P. Dirkse, 291-298. Jakarta: Gramedia Widiasarana Indonesia (Grasindo): Perwakilan Koninklijk Instituut voor Taal-, Land- en Volkenkunde, 1997.

"Forest Management and Exploitation in Colonial Java, 1677-1897." In Agriculture, Resource Exploitation, and Environmental Change, edited by H. Wheatley, 291-311. Aldershot/Brookfield: Variorum, 1997. [An Expanding World; The European Impact on World History 1450-1800, Vol. 17.]

"Introducing Environmental Histories of Indonesia." In Paper Landscapes: Explorations in the Environmental History of Indonesia, edited by P. Boomgaard, F. Colombijn and D. Henley, 1-26. Leiden: KITLV Press, 1997.

"Hunting and Trapping in the Indonesian Archipelago, 1500-1950." In Paper Landscapes: Explorations in the Environmental History of Indonesia, edited by P. Boomgaard, F. Colombijn and D. Henley, 185-213. Leiden: KITLV Press, 1997.

"Selayang Pandang Perkembangan Ekonomi dan Sosial Daerah Comal Periode 17501940." In Di bawah Asap Pabrik Gula: Masyarakat Desa di Pesisir Jawa Sepanjang Abad ke-20, edited by H. Kano, F. Hüsken and Djoko Surjo, 11-40. Yogyakarta: Gadjah Mada University Press, 1996.

“Dutch Medicine in Asia, 1600-1900." In Warm Climates and Western Medicine: The Emergence of Tropical Medicine, 1500-1900, edited by D. Arnold, 42-64. Amsterdam/ Atlanta: Rodopi, 1996.

"Geld, Krediet, Rente en Europeanen in Zuid- en Zuidoost-Azië in de Zeventiende Eeuw." In Kapitaal, Ondernemerschap en Beleid: Studies over Economie en Politiek in Nederland, Europa en Azië van 1500 tot Heden. Afscheidsbundel voor Prof. dr. P.W. Klein, edited by C.A. Davids, W. Fritschy and L.A. van der Valk, 483-510. Amsterdam: NEHA, 1996.

"Forests and the Advance of Agriculture." In Indonesian Heritage: Early Modern History, edited by A. Reid, 14-15. Singapore: Archipelago Press, 1996. 
"Food, Feasting and Famines." In Indonesian Heritage: Early Modern History, edited by A. Reid, 15-16. Singapore: Archipelago Press, 1996.

"Dutch Rule and the Population Explosion." In Indonesian Heritage: Early Modern History, edited by A. Reid, 122-123. Singapore: Archipelago Press, 1996.

"Sacred Trees and Haunted Forests in Indonesia Particularly Java, Nineteenth and Twentieth Centuries." In Asian Perceptions of Nature: A Critical Approach, edited by O. Bruun and A. Kalland, 47-62. Richmond, Surrey: Curzon Press, 1995.

"Colonial Forest Policy in Java in Transition, 1865-1916." In The Late Colonial State in Indonesia: Political and Economic Foundations of the Netherlands Indies 1880-1942, edited by R. Cribb, 117-137. Leiden: KITLV Press, 1994.

"De Bibliotheek, de Indonesië-studies en de Overheid." In Arends Repertorium. De

Centrale Bibliotheek van 1971 tot 1993, 43-45. Amsterdam: KIт Press, 1993. [Bulletin 327, Royal Tropical Institute.]

"Economic Growth in Indonesia, 500-1990." In Explaining Economic Growth, edited by A. Szirmai, B. van Ark and D. Pilat, 195-216. Amsterdam: Elsevier Science Publishers, 1993 .

"Upliftment Down the Drain?: Effects of Welfare Measures in Late Colonial Indonesia." In Development and Social Welfare: Indonesia's Experiences under the New Order, edited by J.-P. Dirkse, F. Hüsken and M. Rutten, 247-253. Leiden: KITLV Press, 1993.

"Illicit Riches: Economic Development and Changing Attitudes towards Money and Wealth as reflected in Javanese Popular Belief." In New Challenges in the Modern Economic History of Indonesia, edited by J.Th. Lindblad, 197-215. Leiden: Programme of Indonesian Studies, 1993.

"Protection de la Nature en Indonésie pendant la Fin de la Période Coloniale (18891949)." In Revue Française d'Histoire d'Outre-Mer 80 (299) (1993): 307-344. [Also in J. Pouchepadass (ed.), Colonisation et Environnement, 307-344. Paris: Société Française d'Histoire d'Outre-Mer, 1993.]

"De eerste Antropoloog." In Aangeraakt door Insulinde, edited by P. Boomgaard, H. Poeze en G. Termorshuizen, 9-13. Leiden: KITLV Uitgeverij, 1992.

"Exploitation and Management of the Surinam Forests 1600-1975." In Changing Tropical Forests. Historical Perspectives on Today's Challenges in Central \& South America, edited by H.K. Steen and R.P. Tucker, 252-264. [n.p.]: Forest History Society, 1992. [Proceedings of a conference sponsored by the Forest History Society and IUFRO Forest History Group.]

"Sacred Trees and Haunted Forests - Indonesia, particularly Java, 19th and 2oth Centuries." In Asian Perceptions of Nature. Papers presented at a Workshop, NIAS, Copenhagen, Denmark, October 1991, edited by O. Bruun and A. Kalland, 39-53. Copenhagen: NIAS, 1992. [Nordic Proceedings in Asian Studies, No. 3.] 
"Changing Economy in Indonesia." In The Colonial Past: Dutch Sources on Indonesian History, edited by P. Boomgaard, 54-61. Amsterdam: KIT, 1991. [Bulletin 323, Royal Tropical Institute.]

With Susan Legêne. "Introduction." In The Colonial Past: Dutch Sources on Indonesian History, edited by P. Boomgaard, 7-11. Amsterdam: KIT, 1991. [Bulletin 323, Royal Tropical Institute.]

"The Non-agricultural Side of an Agricultural Economy, Java, 1500-1900." In In the Shadow of Agriculture: Non-farm Activities in the Javanese Economy, Past and Present, edited by P. Alexander, P. Boomgaard and B. White, 14-40. Amsterdam: KIT, 1991.

"Changing Measures and Measuring Changes: Regional Agricultural Growth in Java, 1815-1875." In Indonesian Economic History in the Dutch Colonial Era, edited by A. Booth, W.J. O'Malley and A. Weidemann, 111-135. New Haven: Yale University Press, 1990. [Monograph series 35, Yale University Southeast Asia Studies.]

"Klimaat, Krokodillen en Kapitalisme: Economische en Sociale Geschiedenis van Zuidoost-Azië 1500 tot Heden." In Onderzoek in Zuidoost-Azië:Agenda's voor de jaren Negentig, edited by H. Schulte Nordholt, 51-62. Leiden: Vakgroep Talen en Culturen van Zuidoost-Azië en Oceanië, RUL, 199o. [Semaian 3.]

“The Javanese Rice Economy 800-180o." In Economic and Demographic Development in Rice Producing Societies: Some Aspects of East Asian Economic History (1500-1900), edited by A. Hayami and Y. Tsubouchi, 142-161. Leuven: Leuven University Press, 1990. [Studies in Social and Economic History 6.]

“The Javanese Rice Economy 800-1800." In Economic and Demographic Development in Rice Producing Societies: Some aspects of East Asian Economic History (150o-19oo), edited by A. Hayami and Y. Tsubouchi, 317-344. Tokyo: [Keio University] 1989.

"Pokken en Vaccinatie op Java, 1780-1860: Medische Gegevens als Bron voor de Demografische Geschiedenis." In Nederlandse Geneeskunde in de Indische Archipel 1861-1942, edited by A.M. Luyendijk-Elshout et al., 115-127. Amsterdam/Atlanta: Rodopi, 1989.

"Smallpox and Vaccination on Java, 1780-1860: Medical Data as a Source for Demographic History." In Dutch Medicine in the Malay Archipelago, 1816-1942, edited by A.M. Luyendijk-Elshout et al., 119-131. Amsterdam/Atlanta: Rodopi, 1989.

“Java's Agricultural Production, 1775-1875." In Economic Growth in Indonesia, 1820-1940, edited by Angus Maddison and Gé Prince, 97-131. Dordrecht/Providence: Foris, 1989. "Treacherous Cane: The Java Sugar Industry between 1914 and 1940." In The World Sugar Economy in War and Depression, 1914-1940, edited by B. Albert and A. Graves, 157169. London/New York: Methuen, 1988.

"Mengubah Ukuran dan Perubahan Ukuran: Pertumbuhan Pertanian Daerah di P. Java 1815-1875." In Sejarah Ekonomi Indonesia, edited by Anne Booth et al., 165-196. Jakarta: $\mathrm{LP}_{3} \mathrm{ES}, 1988$. 
"Forests and Forestry in Colonial Java, 1677-1942." In Changing Tropical Forests: historical perspectives on today's challenges in Asia, Australasia and Oceania, edited by J. Dargaval, K. Dixon and N. Semple, 59-87. Canberra: CRES, 1988.

"Morbidity and Mortality in Java, 1820-1880: Changing Patterns of Disease and Death." In Death and Disease in Southeast Asia: Explorations in Social, Medical and Demographic History, edited by N.G. Owen, 48-69. Singapore: Oxford University Press, 1987. [Asian Studies Association of Australia; Southeast Asia Publication Series, 14.]

"Tegen Duizendpoten, Duikboten en Shylock Ruys: Bouwvakstakingen in Nederland tussen de Wereldoorlogen." In Exercities in ons Verleden: Twaalf Opstellen over de Economische en Sociale Geschiedenis van Nederland en Koloniën, 1800-1950: Aangeboden aan Prof. W.J. Wieringa, edited by P. Boomgaard et al., 129-152. Assen: Van Gorcum, 1981.

"Methodological Problems in comparing strike Incidence with Long and Short Waves." In Konjunktur, Krise, Gesellschaft, edited by D. Petzina and G.v. Roon, 256-259. Stuttgart: Klett Cotta, 1981.

"Bevolkingsgroei en Welvaart op Java (1800-1942)." In Indonesië Toen en Nu, edited by R.N.J. Kamerling, 35-52. Amsterdam: Intermediair bibliotheek, 1980.

"Brazilië: Een Reus op Lemen Voeten?" In Spectrum Jaarboek 1979, 176-184. Utrecht/ Antwerpen: Het Spectrum, 1979.

"Geschiedenis (1873-1975)." In Encyclopedie van Suriname, edited by C.F.A. Bruijning and J. Voorhoeve, 240-245. Amsterdam/Brussel: Elsevier, 1977.

"Vrijheid in Afhankelijkheid: 100 jaar Economische Ontwikkeling na het Einde van het Staatstoezicht in Suriname (1873-1973)." In Suriname: Van Slavernij naar Onafhankelijkheid: De Geschiedenis van Suriname 1674-1974, 63-82. Amsterdam: Os GN, 1975. [Congres verslag, OSGN wetenschappelijke publicaties nr. 3.]

"Stakingen, Vakbondslidmaatschap en Conjunctuur gedurende het Interbellum in Nederland." In Lof der Historie, Opstellen over Geschiedenis en Maatschappij, edited by J. van Herwaarden, 339-373. Rotterdam: Universitaire Pers Rotterdam, 1973. 